\author{
Kuprina N. \\ Ph.D., Associate Professor \\ Department of Accounting and Auditing \\ Odessa National Academy of Food Technologies \\ Kanatna str., 112, Odessa, Ukraine, 65039 \\ E-mail:k.natali@ukr.net
}

\title{
STRATEGIC MANAGEMENT ACCOUNTING AS A TOOL TO PROMOTE COMPETITIVENESS AND EFFICIENCY OF THE ACTIVITY OF THE ENTERPRISE
}

\begin{abstract}
Approaches to the definition of essence of strategic management accounting in scientific works of national and foreign scientists are considered. The objective necessity of its application at the enterprises of Ukraine in the current conditions of the state and development of the economy and market relations which requires the expansion of the range of its objects and methods of management accounting are substantiated. The necessity of adaptation of foreign experience of organization and introduction of strategic management accounting, are considered application of methods of its management to national economic and market conditions, taking into account specificity in Ukraine. The place of strategic management accounting as an instrument in the system of management of the efficiency of their activities and competitiveness in the present conditions is given.
\end{abstract}

Key words: management accounting, strategic management accounting, methods of management accounting, efficiency of activity, competitiveness of the enterprise.

This work is licensed under a Creative Commons Attribution 4.0 International License http://creativecommons.org/licenses/by/4.0/

Statement of the problem and its connection with important scientific and practical tasks. The current state of the Ukrainian economy and the active influence of globalization processes on its development leads to the need of finding tools to ensure the efficiency of functioning and competitiveness of all its entities, therefore, an important role in solving this problem belongs to modern management accounting as an effective instrument of effective management.

The system of management accounting covers a set of techniques, methods, tools, systems, strategies that are selected in accordance with assigned tasks, such as budgeting, ABC analysis, XYZ analysis, analysis of interaction "cost-volume-profit" and "profit-volume ", functional-cost analysis, breakdown analysis, system" just in time "(JIT)," Direct-Costing "and" Standard-Cost "systems, economic value added systems (" EVA "), market value added ("MVA"), Balanced Scorecard ("Balanced Scorecard" - (BSC)), benchmarking, methods for monitoring the effectiveness of asset utilization and repayment of liabilities, etc.

Previous studies have shown that changes in the external environment significantly affect the functioning of the enterprise, ensuring efficient activity and competitiveness, and therefore it is no longer possible to call it an internal economy, namely, it is a system of collection, identification, accumulation, measurement, processing, analysis, preparation and transmission of information about enterprise activity for internal users for making managerial decisions in the process of strategic and current enterprise management [2], which requires further studies for good governance and ensuring the competitiveness and efficiency of national enterprises.

The analysis of the latest publications on the problem. Studies by national and foreign scientists on the state, development, problems and aspects of the application and development of management accounting are reflected in scientific, practical and methodological works of such scientists as I.V.Avercheva, A.Apchera, P.Y. Atamasa, M.V. Baldueva, M.A. Vakhrushina, D.A. Voloshina, V.P. Galenko, R. Harrison, S.F. Golova, Sh. Datara, T.P. Karpova, O.V. Karpenko, O.M. Kostenko, V.E. Kerimova, O.V. Kovaliova, T.A. Koltsova, N.P. Kondrakova, V.S. Lenia, O.G. Lyshchenko, M.Z. Matviychuk, B. Nidlza, L.V. Napadovskaya, M.S. Pushkar, V.S. Rudnitsky, T. Skoun, V.V. Sopka, Ch. Horngren, J. Foster, M.G. Chumachenko, A.D. Sheremeta, L.Yu. Shevtsiv, M.T. Shirba and others, but do not lose their relevance at the present time and require additional research.

Forming of the aims of the research. O.G. Lyshchenko, D.V. Maksymenko, L.V. Chuprina [3-5] state that organization of the modern accounting process at an enterprise should be oriented not only on production but also on the market because most of the information of management accounting is a commercial secret that reflects strategy and tactics of the enterprise under the conditions of competition and that given information is 
oriented not only to meet the needs of current management but also strategic one, which can not be disagreed, which confirms the relevance of this study.

The purpose of the article is to analyze the work of scientists devoted to the directions of development and application of management accounting as a tool of strategic management in order to ensure the efficiency of functioning and competitiveness of national enterprises in modern conditions.

Giving an account of the main results and their substantiation. Modern management accounting uses internal and external information, financial and nonfinancial indicators, provides needs not only of production but also of marketing and other functions of business which L.V. Napadovska underlines [6]. "With the help of management accounting, control and analysis of the implementation of current and long-term goals are carried out. Management accounting provides the effectiveness of management activities of enterprises, their competitiveness and market position. Consequently, the emergence of management accounting system in the conditions of market relations should be regarded as objective necessity. It must solve the problems associated with the new economic situation which are impossible to solve on the basis of the traditional accounting system "[6, p. 126], which needs to expand the range of objects and methods of management accounting.

The previous study showed [2] that changes in management accounting from the internal economic to strategic are considered by scientists in recent publications and studies of national and foreign scientists:

- "information provided by management accounting is oriented to meet the needs of strategic and current management, to optimize the use of resources, to ensure the objective assessment of personnel activities. Management accounting is part of the management process that provides information that is important for defining strategy and planning of the future operations of the organization, controlling current activity, optimization of the use of resources, evaluating the efficiency of activities, reducing of the level of subjectivity in the decision-making ... ultimate purpose of management accounting is to help management in achieving strategic purpose of the enterprise "[4, p. 354-355];

- "formation of modern accounting process should be oriented not only on production, but also on the market. The most of the data of management accounting is a commercial secret, because they reflect the strategy and tactics of the enterprise in a competitive environment ... Therefore, in recent years more and more strategic systems of management accounting are distributed as a result of the desire to expand the information base for decision making through the formation of predictive information "[5, p. 157];

- "for achievement competitive advantages, formation of positive image of enterprise, gaining trust from lenders, investors and partners, management should have complete information of strategic character" [7];

- "The need for management accounting at the national enterprises is primarily due to: ... the aggravation of competition at the internal and foreign markets of domestic products, which requires timely information on their business conditions; integration of Ukraine's economy into the world economic space which inevitably leads to reorientation of both practice and theory of accounting knowledge "[8, p. 299-300];

- "strategic management accounting is exactly designed to enable the enterprise to master new forms, methods and principles of management for dealing with other competitive enterprises" in the conditions of innovation changes and growing competition [3, p. 59];

- "provision and analysis of management accounting data for business and its competitors which are used to monitor and develop the strategy of such business" [9, p. 84] and etc.

Implementation of managerial strategic accounting as instrument for managing the competitiveness of enterprises was considered by foreign scientists in the 20th century [9-10]. Thus, K. Ward emphasizes the need to reflect the relative financial results of strategic management in relation to competitors, suppliers and even consumers [3, p. 59]. According to P.Y. Atamas [10], strategic management accounting is focused on external factors, for example, market share and profitability of competitors.

Theoretical and practical aspects of implementing strategic management accounting at enterprises and financial institutions in Ukraine were conducted by O.G. Lyshchenko and Yu.A. Gerasymenko (table 1) [3].

Authors note that P.Y. Atamas, V.V. Pankov, V.F. Nesvetailov, K.Word consider strategic management accounting as its separate type unlike V.Z. Semanuk, A.V. Shaikan - only as a subsystem of accounting, and O. B. Suloev, K.E. Zemliakova, B. Rhine - as the process [3, p. 60], and in their opinion the main technologies of strategic management accounting (it is more correctly to say the methods, in our opinion), to ensure high competition are [3, p. 62-63]:

- activity-basedcosting (ABC) - accounting of expenses by the type of activity;

- lifecycle costing - calculation of stages of the lifecycle;

- target costing - pricing by targets;

- balanced Scorecard (BSC) is a balanced system of indicators in the management of key business processes of the centers of responsibility of the organization in accordance with the set goal, quantitatively and qualitatively identified in the target values of the evaluation criteria;

- benchmarking is a constant process of studying and evaluating goods, services, production experience of the most serious competitors recognized as leaders in their industries;

- budgeting or standard evaluation is the way to collect information that is used to identify the best practices of other companies.

For the efficient development of national enterprises, ensuring the efficiency of their activities and competitiveness in modern conditions, adaptation of the foreign experience of organization and management of strategic management accounting to the national 
Definition of the essence of the concept of "strategic management accounting "[3, p. 60]

\begin{tabular}{|l|l|}
\hline \multicolumn{1}{|c|}{ Author } & \multicolumn{1}{|c|}{ Definition } \\
\hline P.Y. Atamas & $\begin{array}{l}\text { Accounting that is focused on external factors (such as profitability of clients, market } \\
\text { share, etc.), while traditional accounting is characterized by focus on internal } \\
\text { processes and phenomena. }\end{array}$ \\
\hline K. Ward & Accounting for strategic management. \\
\hline $\begin{array}{l}\text { V.V. Pankov, } \\
\text { V.F. Nesvetailov }\end{array}$ & $\begin{array}{l}\text { Accounting aimed at supporting of strategic decisions is closely linked to market- } \\
\text { oriented external information that has both financial and non-financial nature, aimed } \\
\text { not only at fixing specific trends, patterns but more on tracking trends, patterns or } \\
\text { significant changes, operates with planned and predictable data of long-term nature. }\end{array}$ \\
\hline V.Z. Semanyuk & $\begin{array}{l}\text { Subsystem of accounting, function of strategic management which provides managers } \\
\text { with information about internal environment of the enterprise to make strategic } \\
\text { decisions. }\end{array}$ \\
\hline A.V. Shaikan & $\begin{array}{l}\text { Element of the theory of enterprise management, accounting policy in particular. } \\
\text { Accounting for strategic management purposes. }\end{array}$ \\
\hline $\begin{array}{l}\text { V.V. Ivanov, } \\
\text { O.K. Khan }\end{array}$ & $\begin{array}{l}\text { Means of informational support for making, implementation and evaluation of } \\
\text { strategic management decisions of systematic collection and processing of indicators } \\
\text { that characterize the state of not only internal financial and economic activity but also } \\
\text { external environment (competitive, client, etc.) which is managed by organization. }\end{array}$ \\
\hline K. Simonds & $\begin{array}{l}\text { Providing and analyzing management accounting data for business and its competitors } \\
\text { which are used to monitor and develop the strategy of such business. }\end{array}$ \\
\hline $\begin{array}{l}\text { S.B. Suloyeva, } \\
\text { K.E. Zemliakova }\end{array}$ & $\begin{array}{l}\text { Process of providing information aimed at the long-term perspective should provide } \\
\text { support for overall competitive strategy of organization. }\end{array}$ \\
\hline
\end{tabular}

economic and market conditions, taking into account the specifics of traditions in the production and consumption of goods, the activity of industrial enterprises in Ukraine, etc., are necessary. Thus, the efficiency of the economic activity of enterprises in food industry in the current conditions of changing the environment, the ways and possibilities of achieving the best results for each of the enterprises in this sector is subject to continuous monitoring of activities and changes to ensure and increase the competitiveness and efficiency of their functioning which requires the use of a set of measures which will allow to adapt industrial enterprises to the new conditions of the external and internal environment and their efficiency implementation lead to the need for soft adaptation measures or the imparity of their restructuring of enterprises as transformation of their activities. The analysis of approaches in scientific publications of scientists regarding the evaluation of the efficiency of activities of both individual company and their associations has confirmed a large number of approaches that can be used as a tool for its evaluation and ensuring the efficiency of their activities, but other methods may also be used, for example, a method for assessing the persistence of enterprise, as a measure of its sustainability proposed by us and justified [11, p. 23]. Implementation of such analysis and evaluation are not possible without qualitative organization and management accounting, namely strategic one (fig. 1).

So, in our opinion, using the method of "activitybasedcosting $(\mathrm{ABC}) "$ - accounting of expenses by the types of activity based on their allocation of costs (cost factors) in accordance with the volumes and structure of resources consumed in the process of performing transactions with creation and production it is necessary to evaluate both own and combined activities of the enterprise, the allocation of which is justified by us. To assess the efficiency of their own activities of enterprises and their associations, the system of indicators has been developed and proposed which covers not only the activities of such enterprise and its individual types, it also assesses the efficiency of the functioning of each of the aggregate of enterprises forming the agroindustrial formations and the activities of the whole association in general, taking into account the principle of transparency [11, p. 21-23].

Conclusions and prospects of the further investigations. The conducted research showed that:

- management accounting in modern conditions has not only internal economic character and is based on internal factors of formation of information for management of the enterprise but also on external factors for ensuring the competitiveness of products and maintaining the position on the market, profitability of production and obtaining positive financial results from all types of activities, that is providing financial and economic security and efficiency of all types of activity and competitiveness;

- appearance of a new system of management accounting - strategic management accounting in the conditions of market relations should be regarded as an objective necessity that needs to expand the range of its objects and methods of management accounting;

- for efficient development of national enterprises, ensuring the efficiency of their activities and competitiveness in modern conditions, adaptation of the foreign experience of organization and conducting of strategic managerial accounting to the national economic and market conditions, taking into account specificity in Ukraine are is necessary; 


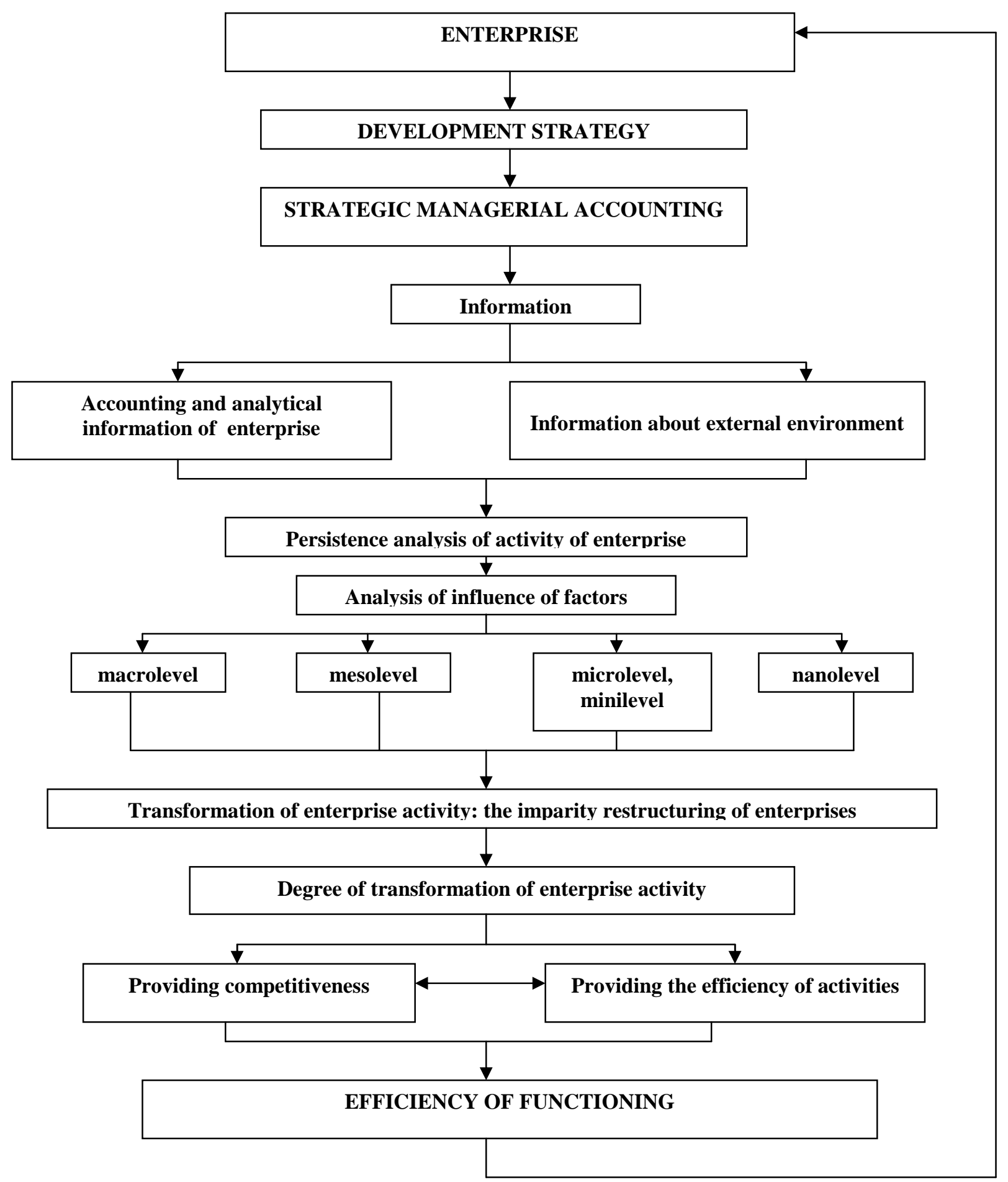

Fig. 1 - Strategic management accounting in the system of management of efficiency of their activities and competitiveness in modern conditions*

* developed by the author

- ensuring of the efficiency of economic activity of enterprises in the current conditions of changing the environment and their competitiveness, ways and opportunities for achieving the best results for each of the enterprises in this sector is subject to continuous monitoring of activities and changes which requires the application of a set of measures that will allow adapting industrial enterprises to new conditions of external and internal environment and the efficiency of their functioning - assessment of the persistence of activities and carrying out soft adaptation measures or imparity restructuring of enterprises as transformation of their activities. Implementation of such analysis is not possible without qualitative organization and conducting of managerial accounting, namely, strategic one. 


\title{
References
}

1. Nemchenko, V. V., Trishyn, F. A., Ivanchenkova, L. V., \& . Tkachuk, H. .. (2015). Oblikovo-analitychne zabezpechennia $\mathrm{v}$ umovakh upravlinnia finansovo-ekonomichnoiu bezpekoiu pidpryiemstva: . Odessa: Feniks.

2. Kuprina , N. M., Nemchenko, V. V., . Ivanchenkova, L. V., \& Tkachuk, H. .. (2017). Orhanizatsiia upravlinskoho obliku: aspekt stratehichnoho upravlinnia // Rozvytok finansovoi systemy suchasnoho pidpryiemstva: oblikovo-analitychnyi aspekt . Odessa: Feniks.

3. Lyshchenko, O. H., \& . Herasymenko, I. A. (2016). Stratehichnyi upravlinskyi oblik yak efektyvnyi instrument upravlinnia konkurentospromozhnistiu . Derzhava ta rehioni. Seriia «Ekonomika ta pidpryiemnytstvo», 1(87), 59-67.

4. Maksymenko D.V. Upravlinskyi oblik yak systema informatsiinoho zabezpechennia upravlinskykh rishen. Retrieved August 17, 2017, from Rezhym dostupu: http://www.irbis-nbuv.gov.ua/cgi-bin/irbis_nbuv/cgiirbis 64.exe? $\mathrm{C} 21 \mathrm{COM}=\mathrm{F} \& \mathrm{I} 21 \mathrm{DBN}=\mathrm{UJRN} \& \mathrm{P} 21 \mathrm{DBN}=\mathrm{UJRN} \& \mathrm{~S} 21 \mathrm{CNR}=20 \& Z 21 \mathrm{ID}$.

5. Chupryna, L. V. (2014). Upravlinskyi oblik v suchasnomu menedzhmenti pidpryiemstva . Visnyk NTU «KhPI», 34, 154-157.

6. Pylypenko, I. I., Shevchuk, V. O., \& Napadovska, L. V. (2003). Modyfikatsiia system obliku ta audytu v umovakh hlobalizatsii ekonomiky . Visnyk Zhytomyrskoho derzh. tekhnol. un-tu: Ekonomichni nauky, 2(24), 123-130.

7. Radchenko, K. O. (2002). Problemnyi upravlinskyi oblik ta yoho prohnostychna funktsiia . Portal dlia upravlintsiv, 10, 24-31.

8. Petrik , O. (2012). Upravlinskyi oblik ta problemy yoho vprovadzhennia v suchasnykh umovakh na pidpryiemstvakh Ukrainy. Zbirnyk naukovykh prats DETUT. Seriia «Ekonomika i upravlinnia», 21-22, 2nd ser., 299304.

9. Simmonds, K. (2006). The accounting assessment of competitive position. European Journal of Marketing. Organization and Society, 1, 84-95.

10. Atamas, P. I. (2006). Upravlinskyi oblik: navch. posib. . K.: Tsentr navchalnoi literatury.

11. Kuprina, N. M. (2016). Efektyvnist diialnosti pidpryiemstv ta yikh ob'iednan: analiz, monitorynh, zabezpechennia. Ekonomika kharchovoi promyslovosti, (1), 8th ser., 19-25; DOI: 10.21691/fie.v8i1.51

\author{
Куприна Н.M. \\ кандидат экономических наук, доцент \\ кафедра учёта и аудита \\ Одесская национальная академия пищевых технологий \\ ул. Канатная, 112, г. Одеса, Украина, 65039 \\ E-mail:k.natali@ukr.net
}

\section{СТРАТЕГІЧНИЙ УПРАВЛІНСЬКИЙ ОБЛІК ЯК ІНСТРУМЕНТ ЗАБЕЗПЕЧЕННЯ КОНКУРЕНТОСПРОМОЖНОСТІ ТА ЕФЕКТИВНОСТІ ДІЯЛЬНОСТІ ПІДПРИЄМСТВА}

Метою статті $€$ аналіз праць вчених, присвячених напрямам розвитку та застосування управлінського обліку, як інструменту стратегічного управління, з метою забезпечення ефективності функціонування та конкурентоспроможності вітчизняних підприємств в сучасних умовах.

В процесі дослідження використовувались методи: системного аналізу, порівняльного аналізу (для аналізу підходів вчених щодо визначення сутності поняття «стратегічний управлінський облік»); методи теоретичного узагальнення (для дослідження понятійного апарату категорій внутрішньогосподарський «управлінський облік» та «стратегічний управлінській облік» та його застосування як інструменту при проведенні імпаритетної реструктуризації підприємств); системного аналізу та синтезу (для визначення сучасних методів стратегічного управлінського обліку).

Проведене дослідженні підтвердило, що управлінський облік в сучасних умовах має не тільки внутрішньогосподарський характер та базується на внутрішніх факторах фрормування інформації для управління підприємством, але й на зовнішніх фракторах для забезпечення конкурентоспроможності продукції та збереження позиції на ринку, рентабельності виробництва та отримання позитивного фінансового результату від віх видів діяльності. Виникнення нової системи управлінського обліку - стра- 
тегічного управлінського обліку в умовах ринкових відносин необхідно розцінювати як об'єктивну необхідність, що потребує розширення кола його об'єктів та методів. Для ефективного розвитку вітчизняних підприємств, забезпечення конкурентоспроможності в сучасних умовах необхідна адаптація зарубіжного досвіду організації та веденні стратегічного управлінського обліку к національним економічним та ринковим умовам, врахування специфіки саме в Україні. Наукова новизна полягає у обґрунтуванні застосування стратегічного управлінського обліку як інструменту проведення імпаритетної реструктуризації підприємств з метою забезпечення конкурентоспроможності та ефективності діяльності підприємств. Практична значущість: отримані результати направлені на забезпечення ефективності функціонування та конкурентоспроможності вітчизняного виробника харчової продукції в України та удосконалення його обліково-аналітичногозабезпечення в системі управління.

Ключові слова: управлінський облік, стратегічний управлінський облік, методи управлінського обліку, ефективність діяльності, конкурентоспроможність підприємства, трансформація діяльності підприємства.

\author{
Купріна Н.M. \\ кандидат економічних наук, доцент \\ кафедра обліку та аудиту \\ Одеська національна академія харчових технологій \\ вул. Канатна, 112, г. Одеса, Україна, 65039 \\ E-mail: k.natali@ukr.net
}

\title{
СТРАТЕГИЧЕСКИЙ УПРАВЛЕНЧЕСКИЙ УЧЕТ КАК ИНСТРУМЕНТ ОБЕСПЕЧЕНИЯ КОНКУРЕНТОСПОСОБНОСТИ И ЭФФЕКТИВНОСТИ ДЕЯТЕЛЬНОСТИ ПРЕДПРИЯТИЯ
}

Целью статьи является анализ работ ученых, посвященных направлениям развития и применения управленческого учета, как инструмента стратегического управления для обеспечения эффективности функционирования и конкурентоспособности отечественных предприятий в современных условиях.

В процессе исследования использовались методы: системного анализа, сравнительного анализа (для анализа подходов ученых к определению сущности понятия «стратегический управленческий учет»); методы теоретического обобщения (для исследования понятийного аппарата категорий внутреннехозяйственный «управленческий учет» и «стратегический управленческой учет» и его применение в качестве инструмента при проведении импаритетной реструктуризации предприятий); системного анализа и синтеза (для определения современных методов стратегического управленческого учета).

Проведенные исследования подтвердили, что управленческий учет в современных условиях имеет не только внутрихозяйственный характер и базируется на внутренних факторах формирования информации для управления предприятием, но и на внешних факторах для обеспечения конкурентоспособности продукции и сохранения позиций на рынке, рентабельности производства и получения положительного фринансового результата от вех видов деятельности. Возникновение новой системы управленческого учета - стратегического управленческого учета в условиях рыночных отношений необходимо расценивать как объективную необходимость, что потребует расширение круга его объектов и методов. Для эффективного развития отечественных предприятий и обеспечения эффеектиности их конкурентоспособности в современных условиях необходима адаптация зарубежного опыта организации и ведении стратегического управленческого учета к национальным экономическим и рыночным условиям, учета специфики именно в Украине. Научная новизна заключается в обосновании применения стратегического управленческого учета, как инструмента проведения импаритетной реструктуризации предприятий, для обеспечения конкурентоспособности и эффективности дительности предприятий. Практическая значимость: полученные результаты направлены на обеспечение эффективности функционирования и конкурентоспособности отечественного производителя пищевой продукции в Украине и совершенствование его учетно-аналитического обеспечения в системе управления.

Ключевые слова: управленческий учет, стратегический управленческий учет, методы управленческого учета, эфффективность деятельности, конкурентоспособности ность предприятия, трансформация деятельности предприятия. 


\section{Література}

1. Обліково-аналітичне забезпечення в умовах управління фінансово-економічною безпекою підприємства: [монографія] / [В.В. Немченко, Ф,А, Трішин,Л.В. Іванченкова, Г.О. Ткачук та ін.] ; за заг. ред. д.е.н., проф. В.В. Немченко. - Одеса: Фенікс, 2015. - 360 с.

2. Купріна Н.М. Організація управлінського обліку: аспект стратегічного управління // Розвиток фінансової системи сучасного підприємства: обліково-аналітичний аспект : [монографія] / [В.В. Немченко, Л.В. Іванченкова, Г.О. Ткачук, Н.М. Купріна та ін.] ; за аг. ред. д.е.н., проф. В.В. - Одеса: Фенікс, 2017. - С. 113-119

3. Лищенко О.Г. Стратегічний управлінський облік як ефективний інструмент управління конкурентоспроможністю / О.Г. Лищенко, Ю.А. Герасименко // Держава та регіоні. Серія «Економіка та підприємництво». 2016. - №1 (87). - С. 59-67

4. Максименко Д.В. Управлінський облік як система інформаційного забезпечення управлінських рішень [Електроний ресурс]. - Режим доступу: http://www.irbis-nbuv.gov.ua/cgi-bin/irbis nbuv/cgiirbis 64.exe? $\mathrm{C} 21 \mathrm{COM}=\mathrm{F} \& \mathrm{I} 21 \mathrm{DBN}=\mathrm{UJRN} \& \mathrm{P} 21 \mathrm{DBN}=\mathrm{UJRN} \& \mathrm{~S} 21 \mathrm{CNR}=20 \& \mathrm{Z} 21 \mathrm{ID}$.

5. Чуприна Л.В. Управлінський облік в сучасному менеджменті підприємства / Л.В. Чуприна // Вісник НТУ «ХПІ». - 2014. - №34. - С. 154-157

6. Пилипенко I.I. Модифікація систем обліку та аудиту в умовах глобалізації економіки / I.I. Пилипенко, В.О. Шевчук, Л.В. Нападовська // Вісник Житомирського держ. технол. ун-ту: Економічні науки. - 2003. - № 2(24). - C. $123-130$

7. Радченко К.О. Проблемний управлінський облік та його прогностична функція / К.О. Радченко / Портал для управлінців. - 2002. - №10. - С. 24-31

8. Петрік О. Управлінський облік та проблеми його впровадження в сучасних умовах на підприємствах України / О.Петрик // Збірник наукових праць ДЕТУТ. Серія «Економіка і управління». - 2012. - Вип. 21-22, Ч. 2. - C. 299-304

9. Simmonds K. / The accounting assessment of competitive position / K. Simmonds // European Journal of Marketing. Organization and Society. - 2006. - №1. - P.84-95

10. Атамас П.Й. Управлінський облік: [навч. посіб.] / П.Й. Атамас. - К.: Центр навчальної літератури, 2006. $-440 \mathrm{c}$.

11. Купріна Н.М. Ефективність діяльності підприємств та їх об'єднань: аналіз, моніторинг, забезпечення / Н.М.Купріна // Економіка харчової промисловості. - 2016. - Т.8, Випуск 1. - С. 19-25; DOI: 10.21691/fie.v8i1.51

Стаття надійшла 14.08.2017 Стаття прийнята до друку 28.08.2017 Доступно в мережі Internet 30.09.2017 